\title{
Evaluating action plans
}

\author{
J.W. Grobbelaar, J.J. Murphy and S.R. van der Walt \\ School of Business Leadership, University of South Africa, Pretoria
}

In 1976 Louis Gerstner wrote, 'one of the most intrigueing management phenomena of the late 1960's has been the rapid spread of the corporate planning concept. Except for the so-called computer revolution, few management techniques have swept through corporate and government enterprise more rapidly or completely'. Yet in spite of this explosion of companies doing corporate planning there are still areas within the process that need to be researched. One such area is the 'evaluation of the action plan'. How do managers decide which portfolio of action plans to select and implement? It has been the authors' experience that these decisions are mostly made on 'gut' feel with a great deal of politicking taking place. In this article a methodology is developed to assist managers in the comparative evaluation of action plans, the final decisions being based on the use of a multivariate model which relates achievement and risk.

S. Afr. J. Bus. Mgmt. 1986, 17: 210-214

Louis Gerstner het in 1976 geskryf dat een van die mees prikkelende bestuursverskynsels van die laat 1960 s sekerlik die snelle verspreiding van die korporatiewe beplanningskonsep was. Buiten die sogenaamde rekenaarrevolusie het min ander bestuurstegnieke so vinnig en volledig deur korporatiewe- en staatsondernemings geswiep. Ten spyte van die ontploffing van korporatiewe beplanning onder maatskappye is daar steeds gedeeltes binne die proses wat nagevors moet word. Een hiervan is die 'evaluasie van die aksieplan'. Hoe kies bestuurders uit die portfolio van aksieplanne watter om te implementeer? Die skrywers het ondervind dat hierdie besluite meestal op aanvoeling berus en dat heelwat politiekery in die proses plaasvind. In hierdie artikel word 'n metodologie ontwikkel wat bestuurders kan help in die vergelykende evaluasie van aksieplanne. Die finale besluite word gebaseer op die gebruik van 'n multivariantmodel wat prestasie en risiko met mekaar in verband bring.

S.Afr. Tydskr. Bedryfsl. 1986, 17: $210-214$

\section{Introduction}

In order to survive, organizations must relate to their environment. As the environment is changing at an ever increasing pace organizations solve the problem of determining their relationship with the environment through the process of planning. Planning reconciles objectives, opportunities and capabilities; it involves selecting ends and means - deciding where you want to be in the future and the best way of getting there.

An intrinsic element or component of this (planning) process is the action plan or programme; i.e. the plan of action to be followed in order to achieve a stated objective.

Perusal of the writings of such authors as Dermer (1977), Anthony \& Dearden (1976), Argenti (1979), and Wilson \& Tomb (1968) highlights the fact that although much is said about the development and structure of an action plan, very little, if any, is mentioned about the evaluation of an action plan. This has prompted the present article.

\section{Definition of an action plan}

Although used by many authors, the term action plan is perhaps best described by Wilson \& Tomb (1968).

'Although no precise format is necessary for expressing and communicatig an action programme each programme should do three things, whatever the format. It should state the objective of the action, detail the steps to be taken and describe the financial impact the action should have'.

Figure 1 illustrates the way an action programme may be expressed.

It is obvious from Figure 1 that as per definition each manager shoud state exactly what he expects to do and he must be prepared to demonstrate that the actions he proposes will be adequate to achieve the planned results. Of particular importance in the further development of our central theme are the following components of an action plan:

(i) Action steps. This entails the different steps required to accomplish the objective. It must be stated in a way that clearly expresses what must be done, who is to do it, and the date by which it is to be completed. This part of the action plan can be considered to be the technical feasibility of the particular programme and will be referred to as such in further deliberations.

(ii) Financial impact. Programmes designed to achieve the profit improvement goal set by the CEO have a plus impact; programmes aimed at improving some management process (e.g. management development) involve a cost which produces an immediate minus profit impact. Virtually all action steps involve some cost implications.
School of Business Leadership, University of South Africa P.O. Box 392, Pretoria, 0001 Republic of South Africa

*To whom correspondence should be addressed 
Objective

Reduce by at least $40 \%$ the frequency and cost of faulty castings received from the XYZ Company.

\begin{tabular}{|c|c|c|}
\hline \multicolumn{3}{|c|}{ Action steps } \\
\hline $\begin{array}{l}\text { Step } \\
\text { Ensure recognition by supplier } \\
\text { of problem with 'hard spots' in } \\
\text { castings }\end{array}$ & $\begin{array}{l}\text { Participation } \\
\text { Purchasing } \\
\text { manager }\end{array}$ & $\begin{array}{l}\text { Timing } \\
\text { Completed }\end{array}$ \\
\hline $\begin{array}{l}\text { Negotiate price concession on } \\
\text { all castings received during } \\
\text { weeks when we return more } \\
\text { than ten bad castings }\end{array}$ & $\begin{array}{l}\text { Purchasing } \\
\text { manager }\end{array}$ & January 31,19 \\
\hline $\begin{array}{l}\text { Set up storage area to accumu- } \\
\text { late ruined castings }\end{array}$ & Facilities manager & January 31,196 \\
\hline $\begin{array}{l}\text { Establish procedures to record } \\
\text { machine downtime and cutter } \\
\text { breakage with individual cast- } \\
\text { ings }\end{array}$ & Production control & February 15,19 \\
\hline $\begin{array}{l}\text { Submit information weekly to } \\
\text { XYZ Company }\end{array}$ & $\begin{array}{l}\text { Purchasing } \\
\text { manager }\end{array}$ & $\begin{array}{c}\text { Begin March } 1 \\
1968\end{array}$ \\
\hline \multicolumn{3}{|c|}{ Profit impact } \\
\hline \multicolumn{3}{|c|}{$\begin{array}{c}1968 \text { Profit } \\
\text { Increase/(Decrease) }\end{array}$} \\
\hline $\begin{array}{l}\text { Price concessions } \\
\text { Effect of improved quality } \\
\text { - Scrap } \\
\text { - Overtime } \\
\text { - Expense tools } \\
\text { - Lost production } \\
\text { Modifications to storage are } \\
\text { Recording procedures } \\
\text { Other costs }\end{array}$ & & $\begin{array}{r}\$ 7,000 \\
8,500 \\
3,500 \\
9,000 \\
20,000 \\
(2,000) \\
(1,000) \\
(3,000)\end{array}$ \\
\hline Total financial impact & & $\overline{542,000}$ \\
\hline
\end{tabular}

Flgure 1 Illustration of action plan (Wilson \& Tomb, 1968).

The financial impact is the net effect of the costs of the action steps and the financial benefit to be derived from the changed conditions.

\section{Delineation of the problem}

It should be noted that major capital expenditure type action programmes (strategic thrusts) are excluded from our discussion. This type of action programme is normally evaluated by the use of such techniques as payback period, discounted cash flow (DCF), cost-benefit or cost-effectiveness analysis and computer simulation models. The level of sophistication is often dictated by the magnitude of the investment involved. In this paper we are concerned with the 'normal' replanning (Kotze, 1983) or management control (Anthony, 1965) type action plan as well as those action plans that are developed as part of the annual business plan.

\section{Generating action plans}

Action plans are generated or triggered during the development of the annual corporate plan as well as part of the management planning and control process during the course of the financial year. Schutte (1981) stated that action plans are triggered by four specific sources, i.e.:

(a) 'by specific strategic guidelines provided by top management as a result of the strategic planning exercise

(b) by the targets set in the strategic plan

(c) SWOT analysis

(d) by the management control process'.

It should however also be noted that there are many other triggers for action plans. If for instance the organization is using quality circles, these will also trigger action plans. Furthermore, some action plans are developed simply as a result of the creativity of the managers or entrepreneurs within the organization.

\section{Evaluating action plans - a literature survey}

Thus far we have been concentrating on the development and the format of action plans. Often the more critical question is how do managers evaluate the different action plans? How do managers select those action plans that not only have the highest probability of completion but also how do they estimate or evaluate the actual profit impact of the action plan? A related question is how do managers prioritize the various action plans? Inspection of the literature indicate that:

(i) Wilson \& Tomb (1968) in their classic publication Integrated Profit Planning and control glossed over the evaluation process by making broad motherhood statements.

(ii) Argenti (1979) also did not offer any concrete methodology by which action plans can be evaluated.

(iii) Dermer (1977) looked at the problem from a process perspective (timing and organization). He did not address the financial aspect of the action plan.

(iv) Anthony \& Dearden (1976) in their discussion on programming in general, and new revenue programmes, manufacturing programmes and support programmes specifically, offered very little by way of a methodology for evaluating these various plans.

(v) Schutte (1981) offered the management review process at various hierarchical levels and times as the vehicle by which to evaluate action plans. It is however clear that the review process as envisaged by Schutte is susceptible to politicking, halo effect, domineering, and bureaucracy and does not offer a solution to the basic problem of evaluation.

(vi) Kotze \& du Preez (1984) analysed the various constituent forecasting elements of the business planning and management control processes and came to the conclusion that the mechanistic forecast is an acceptable instrument to foster creative entrepreneurial planning, i.e. action plans. However, they also did not address the problem of evaluation.

\section{Evaluating action plans - a Monte Carlo simulation approach}

It is seldom possible for a manager to pinpoint exactly the future financial outcome of a proposed action plan. There are many chance uncertainties working in on the plan owing to the unpredictability of environmental factors and even unknown variations in internal factors.

Hence it is maintained that any evaluation of action plans in a business environment must be done in at least two dimensions: financial gain (loss) and financial risk.

To obtain representative figures for net profit and risk the first requirement is to determine the probability distribution of possible profit figures which may materialize if the action plan under consideration is implemented. If we refer to the action plan in Figure 1 we see that such a profit figure can be made up of various positive and negative contributions to profit. Each one has potentially inherent uncertainties.

Hence the problem of the evaluation and comparison of action plans reduces to the following steps:

- estimate the various cost and profit contributions, allowing explicitly for uncertainties;

- combine these estimates into a probability distribution of net profit for the action plan;

- derive representative figures for profit contribution and risk; and

- repeat for other action plans and compare them, along these two dimensions. 


\section{Profit/cost contribution of an action step}

Where there is uncertainty in the profit or cost which will be realized by an action step, the appropriate way to represent this uncertainty quantitatively is by means of a probability distribution. The problem is to obtain a representative form for this distribution and to estimate the required parameters of the distribution.

This is not an unknown problem for the network analyst who has to obtain estimates for the duration of individual activities which make up a PERT network. Experience has taught that knowledgeable people feel more comfortable and are more reliable when asked to give three estimates for the duration of such an activity namely a pessimistic, an optimistic, and a most likely estimate. A beta-distribution is then fitted to these estimates.

The example of PERT analysts is followed here and it is suggested that the financial outcome of each action step be estimated in terms of

$a=$ pessimistic estimate, i.e. the worst value that can realize - barring 'acts of God' not allowed for

$\boldsymbol{m}=$ most likely estimate

$b=$ optimistic estimate, the counterpart of $a$.

In contrast to network analysts it is suggested that the simpler triangular distribution is fitted through the above estimates, and not the beta-distribution. It displays sufficient flexibility whilst accommodating the information contained in the point estimates (see Figure 2) and is easier to work with.

\section{Distribution of net profit}

The net profit of an action plan may be written as

$Z=\sum_{i=1}^{n} X_{i}$

where $Z=$ net profit; $X_{i}=$ revenue (positive) or cost (negative) from action step $i ; i=1,2, \ldots, n$; and $n=$ number of action steps.

The chance uncertainty in revenue and cost components is now contained in different triangular distributions. Thus the net profit is given by a linear combination of a number of random variables with different triangular distributions. This distribution of $Z$ can be complicated even more if it is taken into account that often there is a small but not negligible chance that an action plan will fail and though costs are incurred to all intents and purposes, zero revenue will realize.

Thus it can be seen that the distribution of $Z$ is a difficult one to handle analytically. However, by means of Monte Carlo simulation, it is possible to obtain an adequate representation of its form. For each action step a value is drawn randomly from the corresponding triangular distribution. These are then added to give a representative figure for net profit. This process can now be repeated to build up an empirical distribution of net profit.

Useful displays of such a distribution are the risk function
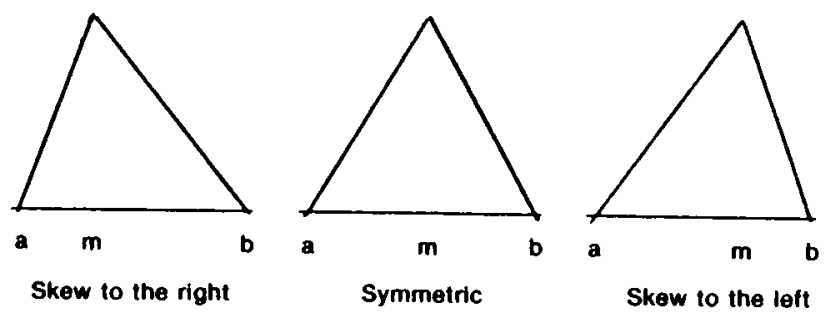

Fizare 2 Examples of triangular distribution with difference in skewness.

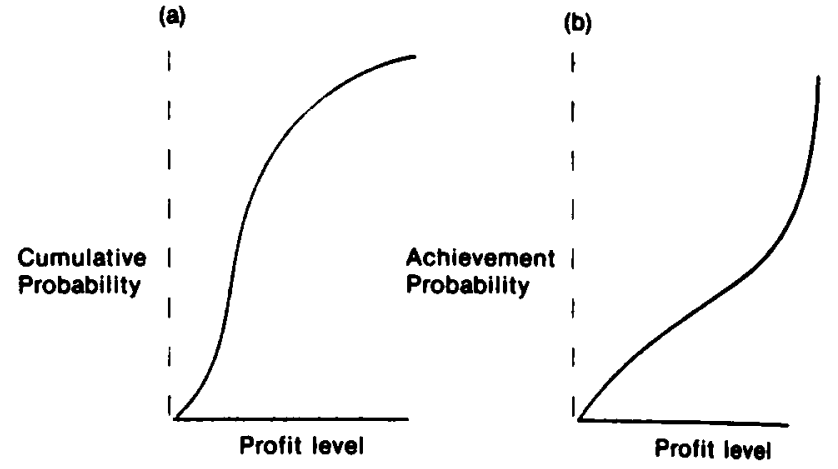

Figure 3 (a) Cumulative distribution function and (b) Achievement probability function.

or cumulative distribution function (Figure 3a) and its complement, the achievement probability function (Figure $3 b$ ). From the risk function one can read off for any level of profit on the horizontal axis the risk (probability of achieving that or less). The achievement probability function gives the probability of achieving a particular level of profit or more.

The illustrative action programme in Figure 1 can be used to illustrate the process and estimates can be made for the various action steps (Table 1). The achievement probability function is displayed in Figure 4.

Table 1 Estimates made for the various action steps

\begin{tabular}{lccc}
\hline Action step & $\begin{array}{c}\text { Pessimistic } \\
\text { estimate }\end{array}$ & $\begin{array}{c}\text { Most likely } \\
\text { estimate }\end{array}$ & $\begin{array}{c}\text { Optimistic } \\
\text { estimate }\end{array}$ \\
\hline Revenue generators & & & \\
$\quad$ Price concessions & 2000 & 7000 & 13000 \\
Overtime & 0 & 8500 & 8500 \\
Expense tools & 3500 & 3500 & 3500 \\
Lost production & 0 & 9000 & 26000 \\
Cost generators & & & \\
$\quad$ Storage area & 8000 & 2000 & 500 \\
Procedures & 2000 & 1000 & 0 \\
Others & 6000 & 3000 & 1300 \\
\hline
\end{tabular}

\section{Representative figures for profit and risk}

In order to compare various action plans according to the two dimensions of net profit and risk it is necessary to obtain for each action plan a single representative figure for net profit and a single figure for risk.

Comparable single values for net profit are expected profit (mean), most likely profit (mode), or median profit. Because an action plan will be employed only once, it is suggested that the most likely profit be used. However, in practice this will often not be an appropriate indicator of achievement, because e.g. for multimodal distributions (i.e. distributions which display more than one peak) the question arises theoretically of which mode to use. In practice it may also be found that the distributions do not display very prominent modes. The expected value has more intuitive appeal whereas the median is more appropriate when outliers can 'distort' the expected value. The median is used in the example below as being more discriminatory. What is really important though is that whichever figure is used, the same measure of locality must be used for all action plans evaluated.

Risk can also be expressed in more than one way. The probability to make a loss, or the probability to make less 
Achievement probability

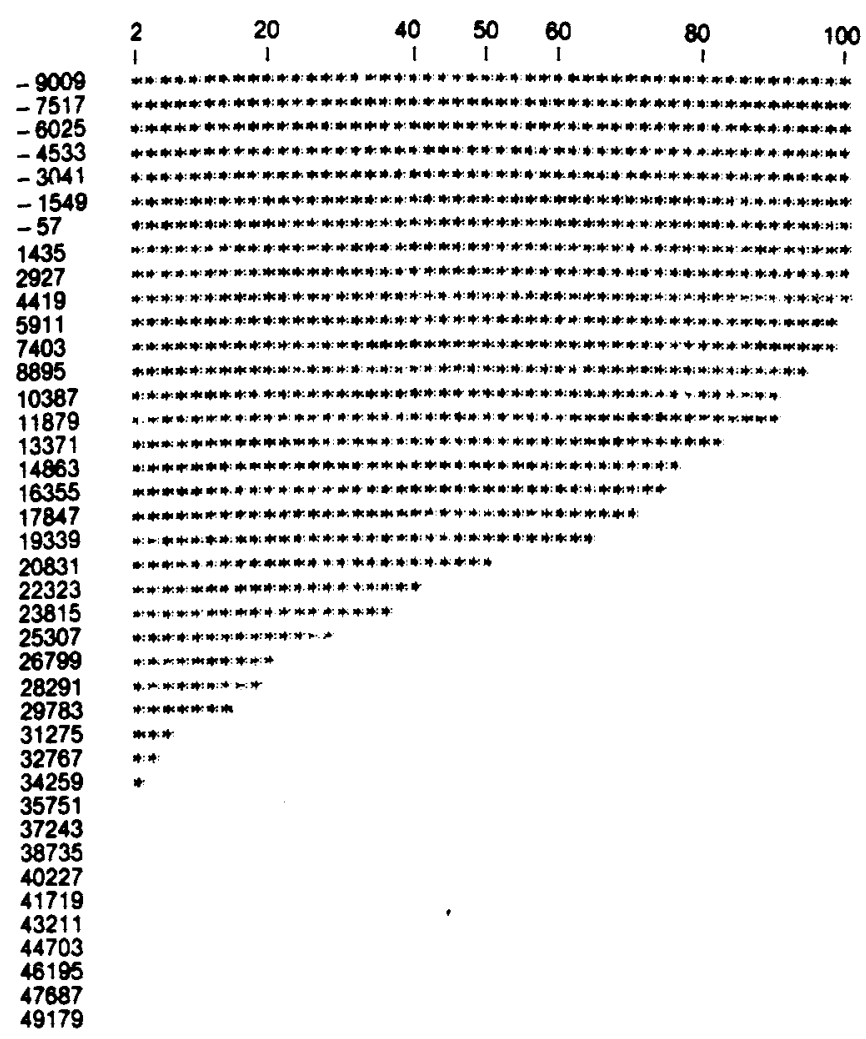

Figure 4 Achievement probability function: Example.

than some acceptable amount of net profit, is an intuitively appealing norm to use and hence is propagated here. It can be read off directly from the risk function. For the example above, the simulation programme gave the following values: Median profit: 20831

Probability of making less than 20000 : $64 \%$

\section{Comparison of action plans}

For the purpose of prioritizing different action plans it is suggested that all action plans to be considered be displayed on the same graph with profit on the horizontal axis and risk on the vertical axis. The example in the next section will illustrate the process.

\section{Example}

The example considered here is a theoretical one and should not be linked to the previous discussion. The purpose is to demonstrate the method as well as to investigate whether some general conclusions may be drawn as to the tendencies that will emerge from different forms of cost generators and revenue generators.

Four different distributions were used for revenue generators showing markedly different forms though having the same mode. Similarly four different cost distributions with the same mode were considered. These were combined to create 16 different combinations ('action plans') each consisting of a different (single) revenue generator and a single cost generator.

The revenue distributions used are given in Table 2. Note that the mode was always the same and the difference between extremity and mode was either 10000 or 40000 . This was also true for cost distributions used (Table 3).

Each combination was simulated 500 times. As a measure of achievement median profit was used. The results are given in Table 4. As measure of risk the probability of obtaining
Table 2 Revenue distributions

\begin{tabular}{lcccc}
\hline Code & Type $^{\mathrm{a}}$ & Lower limit & Mode & Upper limit \\
\hline A & HC & 350000 & 360000 & 370000 \\
B & SR & 350000 & 360000 & 400000 \\
C & SL & 320000 & 360000 & 370000 \\
D & LC & 320000 & 360000 & 400000 \\
\hline
\end{tabular}

${ }^{2} \mathrm{HC}$ : High degree of certainty, i.e. a small range between lowest and highest value.

SR: Skew to the right.

SL: Skew to the left.

LC: Low degree of certainty, i.e. long range between lowest and highest value.

Table 3 Cost distributions

\begin{tabular}{lcccc}
\hline Code & Type $^{\mathrm{a}}$ & Lower limit & Mode & Upper limit \\
\hline 1 & HC & 270000 & 280000 & 290000 \\
2 & SR & 270000 & 280000 & 320000 \\
3 & SL & 240000 & 280000 & 290000 \\
4 & LC & 240000 & 280000 & 320000 \\
\hline
\end{tabular}

aSee Table 2 for explanation of symbols.

Table 4 Median profit

\begin{tabular}{lcrcc}
\hline & \multicolumn{4}{c}{ Revenue } \\
\cline { 2 - 5 } Cost & HC:1 & \multicolumn{1}{c}{ SR:2 } & SL:3 & LC:4 \\
\hline HC:A & 80000 & 88500 & 74000 & 78000 \\
SR:B & 70000 & 78500 & 57500 & 72500 \\
SL:C & 86500 & 101000 & 76000 & 89000 \\
LC:D & 83500 & 87000 & 68500 & 80000 \\
\hline
\end{tabular}

Table 5 Risk (P (profit $<70$ 000))

\begin{tabular}{lrrrr}
\hline & \multicolumn{4}{c}{ Revenue } \\
\cline { 2 - 5 } Cost & HC:1 & SR:2 & SL:3 & LC:4 \\
\hline HC:A & $6 \%$ & $4 \%$ & $38 \%$ & $32 \%$ \\
SR:B & $44 \%$ & $28 \%$ & $70 \%$ & $42 \%$ \\
SL:C & $2 \%$ & $0 \%$ & $30 \%$ & $30 \%$ \\
LC:D & $30 \%$ & $20 \%$ & $72 \%$ & $38 \%$ \\
\hline
\end{tabular}

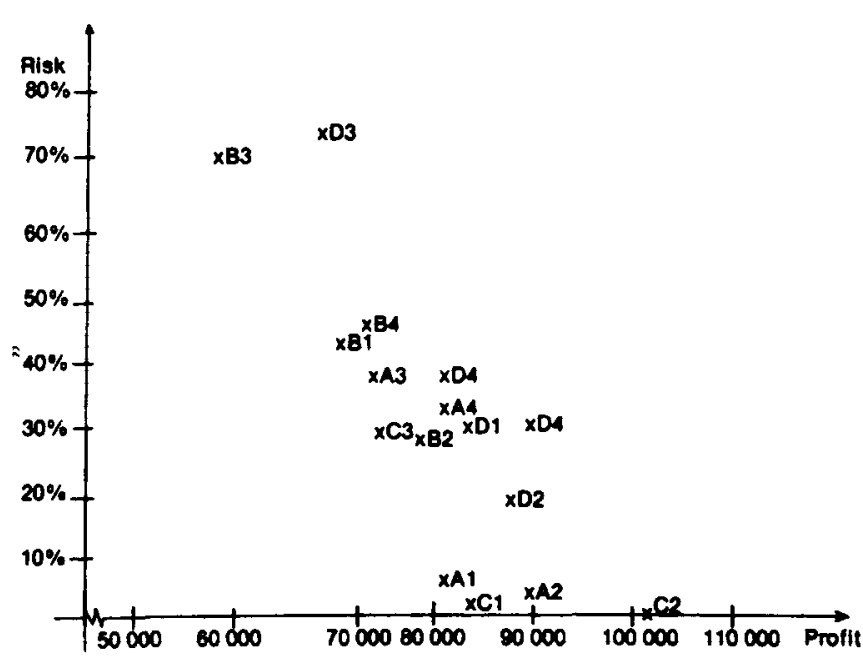

Figure 5 Comparison of action plans. 
less than 70000 profit was used. The results are shown in Table 5 and Figure 5.

\section{Discussion of results}

From Figure 5 it is obvious that combination $\mathrm{C} 2$ (i.e. cost entry $\mathrm{C}$ and revenue entry 2 ) is the most lucrative proposition having the highest representative profit margin (101000) and lowest risk $(0 \%$ probability of obtaining less than 70000$)$.

Similarly $\mathrm{A} 2$ and $\mathrm{Cl}$ are also attractive. The choice between $\mathrm{A} 1$ and $\mathrm{D} 2$ will depend on the preference of management concerned.

\section{General comment}

Although the example is too limited to draw detailed conclusions, two remarks are in order. Firstly, if the revenue distribution is skew to the right or the cost distribution is skew to the left, it has a marked improvement in risk as well as on median profit and vice versa. This is due to the relatively better chance of obtaining a really high revenue and/or low cost. Secondly, there is no definite picture emerging regarding the comparison of high certainty versus low certainty in terms of the criteria used.

\section{Practical application}

In practice the actual cost/revenue distributions will be used in the simulation programme to obtain an achievement probability/risk curve for each action plan. This will aid management to select a portfolio of action plans to close or exceed the planning gap (gap between actual year end profit forecast and profit objection) taking into account management's risk propensity.

Further research is being conducted to develop an optimization model for this purpose.

\section{References}

Anthony, R.N. 1965. Planning and Control Systems. A Framework for Analysis. Division of Research, Graduate School of Business Administration Boston. $185 \mathrm{p}$.

Anthony, R.N. \& Dearden, J. 1976. Management Control Systems. Text and cases. Homewood, Illinois: Richard D Irwin. $769 \mathrm{p}$.

Argenti, J. 1979. Systematic Corporate Planning. Thomas Nelson and Sons Ltd. $316 \mathrm{p}$.

Dermer, J. 1977. Management planning and control systems. Advanced concepts and cases. Homewood, Illinois: Richard D Irwin Inc. $388 \mathrm{p}$.

Kotze, J. Meaningful Managerial Action Planning: The financial component. S. Afr. J. Bus. Mgmt., vol. 14, $156-160$.

Kotze, J. \& Du Preez, N. Dynamic Replanning: Some comments on the Practical Application of the Analytical Forecast. S. Afr. J. Bus. Mgmt., vol. 15, 119-172.

Schutte, F.G. 1981. Integrated Management Systems. Pretoria: Butterworths.

Wilson, S.R. \& Tomb, J.O. 1968. Improving Profits through Integrated Planning and Control. Inglewood Cliffs W J: Prentice-Hall Inc. $162 \mathrm{p}$. 